\title{
Subsoil Characteristics and Hydrogeology of the Export Processing Zone, Calabar-Southeastern Nigeria
}

\author{
${ }^{1}$ YOUDEOWEI, P O; ${ }^{* 2}$ NWANKWOALA, H O \\ ${ }^{\prime}$ Institute of Geosciences and Space Technology, Rivers State University of Science and Technology, P.M.B 5080, Nkpolu, Port Harcourt, \\ Nigeria.
}

$2^{2 *}$ Department of Geology, University of Port Harcourt, P.M.B 5323, Choba, Nigeria

E-mail: hyci2002@yahoo.com

\begin{abstract}
The subsoil characterization and hydrogeological investigation of the Export Processing Zone (EPZ), Calabar Southeastern Nigeria was undertaken using geotechnical analysis of soils and water level monitoring. Geotechnical analysis of soils in the EPZ show that the grain size range from poorly graded (well sorted) to well graded (poorly sorted) soils with very little or no fines $(0.1-5.30 \%$ passing $0.075 \mathrm{~mm}$ sieve). Permeability values vary from $6.80 \times 10^{-3} \mathrm{~cm} / \mathrm{s}$ to $9.43 \times 10^{-3} \mathrm{~cm} / \mathrm{s}$ for the sandy clay to gravelly clay, to $7.00 \times 10^{-1} \mathrm{~cm} / \mathrm{s}$ to $8.70 \times 10^{-1} \mathrm{~cm} / \mathrm{s}$ for the coarse sand to gravelly sand. Soil consistency shows a plasticity range $(7.00-13.00 \%)$ for the clayey soils with the predominantly sandy soil being non-plastic. The local groundwater migration in the area is towards the north easterly direction, meaning that the local flow pattern discharges towards area which has the lowest groundwater elevation. Following this, the implication is that subsurface water migration in the area will move towards and intersect the Calabar River flowing mostly in a southerly direction. This, by implication, will decrease the concentration of probable contaminants due to dispersion and other attenuation effects. Therefore, regular assessment of the subsoil characteristics and hydrogeology of the area will provide baseline data for planning in order to reduce the associated/attendant negative environmental hazards of export processing activities. @ JASEM
\end{abstract}

The export processing zones all over the world are associated with many environmental problems, which have been a subject of primary concern in recent times. Industrial activities have been known to impact on the quality of environmental media such as water, soil, etc. The Export Processing Zone, Calabar southeastern Nigeria is one of the thriving processing zones with associated/attendant environmental hazards. Several environmental problems are expected to occur if no secure and environmental friendly measures associated with development are carried out, as this can prevent severe contamination in soil and groundwater (Bruno, 2007; Barends \& Hagenaar, 2008; Depountis et al, 2009). The uncertainties associated with soil and water quality degradation caused by pollution and other risks as a consequence of man-made interventions will require improved hydro-geotechnical data collection and analysis in order to determine the local groundwater flow direction, and how the pollutants reaching the groundwater will migrate along these flow paths
(Rodriguez, 2006; Hasfurther \& Turner, 2008). This study therefore, is aimed at assessing the subsoil characteristics and hydrogeology of the area and to determine the vulnerability of the area to pollution, as well as generate necessary baseline information that will be useful in planning and also developing an appropriate environmental management programme in order to reduce potential negative effects of export processing activities.

Geomorphology and Geology of the Area: The study area is marked by a highly undulating, rugged topography comprising dissected, irregular terrain of weathered steep ridges and deep troughs. The altitudes vary from about $10-65$ metres above mean sea level with sharp gradation down slope. However, some areas have been graded for construction purposes so that about $10-15$ metres in height have been lost in some places.

The site lies within the Calabar Flank geosyncline 
which extends from the southern margins of the Oban Massif in the easthern hinge line of the Niger Delta in the West (Reijers, 1996). Structurally, the Charcot ocean transform fault separates the Calabar Flank basin from the Niger Delta Basin. Rocks of Cenomenian age occur only north of Calabar which unite together to form the Odukpani group, a late Cretaceous post-rift marine unit believed to have been deposited in a shallow water environment close to the Oban Massif (Reyment, 1996). They consist mainly of the Albian Awi Formation (Conglomerate Sandstone) which underlies the Albian Mfamosing limestone with sediment thickness of over $3,500 \mathrm{~m}$. This is followed by a sequence of lower Turonian sandstone, shales and limestones (Reijers, 1996). Parts of the area are characterized by extensive mangrove forests while other parts have thriving freshwater vegetation with dense growth of raphia palms.

\section{MATERIALS AND METHODS}

Drilling: Three (3) boreholes were sunk with hand-operated light cable percussion rig to maximum depths of $42.00 \mathrm{~m}$ for borehole 1 and $20.00 \mathrm{~m}$ each for boreholes 2 and 3.The wells were logged on site (drillers $\log$ ), with soil samples recovered at intervals where distinct changes in soil type occur, for laboratory analysis of textural characteristics, classification and infiltration properties. Static water levels recorded after drilling for each well were $30.50 \mathrm{~m}, 1.55 \mathrm{~m}$, and $13.85 \mathrm{~m}$, for boreholes 1,2 and 3 , respectively. These data were also related to the ground elevation information of the borehole sites and utilized in determining the groundwater flow direction.

The wells were screened at the aquifer depth, cased and capped with Poly Vinyl Chloride (PVC) plastic pipes and their base cemented.

Soil Textural Analysis: Soil samples recovered from the boreholes were subjected to both visual examination and laboratory testing. The laboratory tests carried out on representative soil samples in accordance with B.S 1377 (1975) are grain size distribution analysis, permeability (using both falling and constant head permeameters) and Atterberg (consistency) limits.

\section{RESULTS AND DISCUSSION}

Soil Stratigraphy: Lithostratigraphic profiles of sediments for each of the three boreholes as shown by ground elevation of boreholes and the strata correlation indicate that the local groundwater flow in the area is towards the northeasterly direction. In boreholes 1 and 2, the top most overburden soil consists of a 1.60 to $3.00 \mathrm{~m}$ thick medium grained, low plasticity clayey sand. This is represented by a $4.00 \mathrm{~m}$ thickness of medium grained, moderately plastic sandy clay in borehole 3. A sequence of detrital materials varying in thickness, grain sizes, relative density and consistency, but with slight colour alterations, underlies these beds. These consist of gravely sand, sand, sandy clay, silty clay, clayey sand, mudstone, and sandstone. Carbonate rocks were observed at depths of about $36.00 \mathrm{~m}$ and $12.40 \mathrm{~m}$ in boreholes 1 and 3, respectively. They are bioclastic limestone bands interstratified with black marine shale, minor reddish brown clay and grayish dolomite. These represent a system of semi-permeable aquitards and essentially impermeable aquicludes which separate and overlie the water- bearing confined aquifer. The clean sand- gravelly sand aquiferous layer was encountered at depths of 15.00 $-19.60 \mathrm{~m}$ in boreholes 2 and 3 . In borehole 1, the first aquifer is occurs at about $30.00 \mathrm{~m}$ while the next is at $42.00 \mathrm{~m}$. The aquifer sediments are of a medium to very coarse texture, angular to sub-angular grained, indicative of a good groundwater aquifer.

Grain Size Patterns: Grain size analysis involved dry sieving on field obtained samples. Results obtained from the grain size analysis of representative soil type of samples from the three boreholes (Table 1) show a range of poorly graded (well sorted) to well graded (poorly sorted) soils with very little or no fines $(0.1-5.30 \%$ passing $0.075 \mathrm{~mm}$ sieve $)$. Infiltration of fluids through the poorly graded, fine grained soils such as the silty clay and sandy clay will be low due to the reduction of void spaces in them. 
Table 1: Subsoil characteristics and hydrogeology of the study area

\begin{tabular}{|c|c|c|c|c|c|c|c|c|c|c|c|}
\hline \multirow{2}{*}{$\begin{array}{l}\text { Borch } \\
\text { ole } \\
\text { Numb } \\
\text { er }\end{array}$} & \multirow[t]{2}{*}{$\begin{array}{c}\text { Deth } \\
(\mathrm{m})\end{array}$} & \multirow{2}{*}{$\begin{array}{c}\text { Soil } \\
\text { group } \\
\text { Nomencla } \\
\text { ture }\end{array}$} & \multicolumn{4}{|c|}{$\begin{array}{c}\text { Grain Size Distribution (Percent } \\
\text { Passing Sieves) }\end{array}$} & \multicolumn{3}{|c|}{ Atterberg limits } & \multirow{2}{*}{$\begin{array}{c}\text { Permea } \\
\text { bility } \\
\text { (cm/se } \\
\text { c.) }\end{array}$} & \multirow{2}{*}{$\begin{array}{l}\text { Classifi } \\
\text { cation }\end{array}$} \\
\hline & & & $\begin{array}{c}(4.75 \\
\mathrm{m})\end{array}$ & $\begin{array}{l}2.00 \\
\mathrm{~mm})\end{array}$ & $0.42 \mathrm{~mm})$ & $\begin{array}{l}0.075 \\
\mathrm{~mm})\end{array}$ & $\mathrm{LL}$ & PL & PI & & \\
\hline & 0.50 & Sand & 99.3 & 96.9 & 58.90 & 1.30 & - & - & $\begin{array}{l}\text { Non- } \\
\text { plastic }\end{array}$ & $7 . \times 10^{-3}$ & SP \\
\hline \multirow[t]{2}{*}{$\mathrm{BHI}$} & 9.60 & $\begin{array}{l}\text { Gravelly } \\
\text { clay }\end{array}$ & 99.9 & 97.6 & 40.30 & 3.00 & 31.0 & 31.0 & 7.00 & $9 \times 10^{-3}$ & SM-SC \\
\hline & 26.0 & Sand & 73.7 & 59.9 & 25.20 & 1.00 & - & - & $\begin{array}{l}\text { Non-p } \\
\text { lastic }\end{array}$ & $7 \times 10^{-1}$ & SP \\
\hline \multirow[t]{2}{*}{$\mathrm{BH} 2$} & 7.00 & $\begin{array}{l}\text { Clayey } \\
\text { sand }\end{array}$ & 100 & 92.0 & 44.00 & 4.00 & 35.0 & 35.0 & 8.70 & $6 . \times 10^{-3}$ & $\mathrm{SC}$ \\
\hline & 8.50 & $\begin{array}{l}\text { Silty } \\
\text { sand }\end{array}$ & 99.0 & 87.3 & 45.00 & 5.30 & 40.0 & 40.0 & 13.00 & $7 \times 10^{-3}$ & $\mathrm{SC}$ \\
\hline \multirow[t]{2}{*}{ BH3 } & 9.50 & $\begin{array}{l}\text { Gravelly } \\
\text { clayey } \\
\text { sand } \\
\end{array}$ & 91.6 & 73.4 & 24.00 & 0.10 & - & - & $\begin{array}{l}\text { Non-p } \\
\text { lastic }\end{array}$ & $8 \times 10^{-1}$ & SW \\
\hline & 19.6 & $\begin{array}{l}\text { Gravelly } \\
\text { sand }\end{array}$ & 90.3 & 70.3 & 13.50 & 0.10 & - & - & $\begin{array}{l}\text { Non-p } \\
\text { lastic }\end{array}$ & $8 \times 10^{-1}$ & SW \\
\hline
\end{tabular}

Permeability: The values obtained from permeability tests of the samples vary from low of $6.80 \times 10^{-3} \mathrm{~cm} / \mathrm{s}$ to $9.43 \times 10^{-3} \mathrm{~cm} / \mathrm{s}$ for the sandy clay to gravelly clay, to moderately high of $7.00 \times 10^{-1} \mathrm{~cm} / \mathrm{s}$ to $8.70 \mathrm{x}$ $10^{-1} \mathrm{~cm} / \mathrm{s}$ for the coarse sand to gravelly sand (Table 1). This renders them potential aquifers. Coefficient of permeability increases with increasing size of voids, which in turn increases with increasing grain size. The larger grains permit more fluid motion as a result of high permeability than the finer ones. The shape of the void spaces also has a marked influence on the permeability.

Soil Consistency: The consistency of the soils in the area was studied by measuring the natural moisture contents, determining both the liquid and plastic limits and the plasticity indices (Atterberg limits). The results are presented in Table 1 . The results show a low plasticity range $(7-13 \%)$, with the predominantly sandy soils being non-plastic. The low values of plasticity indices of the plastic soils is an indication that they have a low water absorbing capacity and may not retain much fluid in them.

The soils fall within the soil classification groups of SP, SW and the borderline Classification of SM-SC (See Table 1) under the unified soil classification system (U.S.C) scheme. Soils with the same classification tend to have the same engineering behaviour (Krynine et al, 1957).

\section{Hydrological Conditions and Sub-Surface Drainage}

Pattern: The hydrology of the study area is governed by its high precipitation rate (mean annual Rainfall of over $2500 \mathrm{~mm}$ ), the overburden lithologic strata that overlie the aquifer, and the undulating topography. Surface waters are either rivers or streams which receive fresh water flows from inland areas.

The Calabar River which flows southwards of the area is reported to be influenced by semi-diurnal tides. (Ramanathan, 1981). The aquifer is confined below aquitards and fewer aquicludes such as the silty clay and mudstone. The ability of these sediments to hold and transmit water is determined by their porosity and permeability. The sandstones will also be good aquifers at relatively shallow depths where most of its primary porosity will still be retained as compaction will be low. This may be the case in Borehole 2. In the carbonate sections, percolating waters with low $\mathrm{pH}$ will enhance the process of solution and hence boost porosity and permeability. Low infiltration rate will promote high run-off at the site which will be facilitated by the slopes. Parameters that influence infiltration include soil type and cover, surface texture, limiting slope value, initial 
moisture content of soil and rainfall intensity. Recharge in the aquifer will be through a distant outcrop of a porous formation and partially through these confining layers.

Groundwater elevations were deduced from groundwater levels and ground elevations of the boreholes. These values were utilized in defining the groundwater table contours, from which the direction of groundwater flow was determined. Flow lines are perpendicular to contours, which show directions of movement (Todd, 1980). Surface water also tends to flow normal to the contour lines of the ground surface. Ground water moves from levels of higher energy to levels of lower energy, whereby energy level is essentially the result of elevation and pressure (Boonstra, 1989). The local ground water flow at the site between boreholes 1,2 and 3 is towards the north-easterly direction. This means that the local flow pattern discharges towards $\mathrm{BH} 2$ which has the lowest groundwater elevation. The subsurface phase of the hydrological cycle of groundwater flow is completed when the groundwater emerges along lines or zones where the water table intersects the ground surface. Subsequently, the subsurface water migration at the site will move towards and intersect the Calabar River, flowing mostly in a southerly direction.

Conclusion: As revealed from this study, the grain size analysis of representative soil type in the area show a range of poorly graded (well sorted) to well graded (poorly sorted) soils with very little or no fines $(0.1-5.30 \%$ passing $0.075 \mathrm{~mm}$ sieve $)$. Soil consistency results show a low plasticity range (7-13\%), with the predominantly sandy soils being non-plastic. The low values of plasticity indices of the plastic soils is an indication that they tend to have a low water absorbing capacity, hence may not retain much water in them. The aquifer sediments are of a medium to very coarse texture, angular to subangular grained, indicative of a good groundwater aquifer. Properties of the overburden confining layers of the study area determine whether or not groundwater contaminants introduced into the soil will reach the aquifer. Following the results of the study, as pollutants reach the groundwater it will tend to move laterally, initially in a north- easterly direction and later in a southerly direction of flow seawards. As the water moves away from the point or line sources of pollution, the concentration of contaminants decreases due to dispersion and other attenuation effects, such as biological decomposition of organic compounds and precipitation of dissolved chemicals(Bouwer,1978). It is therefore recommended that detailed groundwater flow modeling and geotechnical studies be carried out to monitor local flow pattern as well as the subsoil characteristics of the area.

Acknowledgement: The authors express their profound gratitude to Delta Systematics (Nig) Ltd. for the opportunity to engage in the study. Also the useful comments and helpful suggestions of the anonymous reviewers that improved the quality of the paper are greatly acknowledged.

\section{REFERENCE}

Aseez, LO (1989) Review of the stratigraphy, sedimentation and structure of the Niger Delta. In: C.A Kogbe (Ed.) Geology of Nigeria. pp 311-324

Barends, FBJ and Hagenaar, J (2 . Following the Geotechnical Studies of the West-Breaker at Sines: Hydro-Geotechnical Stability of Breakwaters. ASCE Publications Conf. Proceeding Paper, pp124-167.

Boonstra, JI (1989) SATEM: Selected Aquifer test Evaluation Methods. A Microcomputer program. ILRI Publication 48. International Institute for Land Reclamation and Improvement, Wageningen, The Netherlands.

Bouwer, H (1978) Groundwater Hydrology. McGraw Hill Book Co., 480pp.

Bruno, B (2007). Hydro-geotechnical properties of hard rock tailings from metal mines and 
emerging geo-environmental disposal approaches. Canadian Geotechnical Journal, Vol.44 (9):1019-1052.

B.S 1377 (1975) Methods of test for soils for civil engineering purposes. British Standards Institution BSI), London.

Depountis, N; Koukis, G and Sabatakakis, N (2000). Environmental problems associated with the development and operation of a lined and unlined landfill site: A case study demonstrating two landfill sites in Patra, Greeze. Environmental Geology Journal, Springer, Vol.56(7):1251 1258.

Federal Environmental Protection Agency (1994) Guidelines for Environmental Impact Assessment (Decree 86, 1992) Draft Sectoral Guidelines for Oil and Gas Industry Projects.

Freeze, RA; Cherry, JA(1979) Groundwater. Prentice- Hall, Inc.Englewood Cliffs, N.J.

Hasfurther, VR; Turner, JP (2008) Hydrogeotechnical considerations for the disposal of Oil Shale solid waste material. American Society of Civil Engineers (ASCE) Publications, Conf. Proceeding Paper, pp395-400.

Hossain, MT (1981) Geochemistry and Petrology of the Minor Intrusives between Efut Eso and Nko in the Ugop area of Cross Rivers State. Jour. Min. Geology, 18 (1):42-51.

Kogbe, CA (1989) The Cretaceous and Paleogene sediments of Southern Nigeria. In: C.A Kogbe (Ed.) Geology of Nigeria. pp325-334.

Krynine, DP; Judd, WR (1957) Principles of Engineering Geology and Geotechnics. McGraw-Hill Book Company.

Nair, KU; Ramanathan, RM \& Ukpong, EE (1981) Sedimentology and Stratigraphy of Cretaceous carbonates and associated rocks of Calabar Flank, Nigeria. Jour. Min. Geology. 18(1):120-129.

Ramanathan, RM (1981) Ecology and distribution of Foraminifera in Cross River Estuary and Environs of Calabar, Nigeria. Jour. Min. Geol.,18(1):154-162).

Reijers, TJA (1996) Aspects of the Geology of Nigeria, Ibadan Univ. Press.133pp

Rodriguez, R (2006) Hydrogeotechnical characterization of a metallurgical waste. Canadian Geotech J, 43 (10): 1042-1060.

Short, KC and Stauble, AS (1967) Outline of the Geology of the Niger Delta. Bull. A.A.P.G, Vol.51:761-779.

Todd, DK (1980) Groundwater Hydrology. $2^{\text {nd }}$ Edition, John Wiley and Sons Inc. N.Y

Youdeowei, PO (1995) Outline of geo-electric survey and stratigraphic interpretation for water well location at an industrial setting in southeastern Niger Delta. $8^{\text {th }}$ Annual Conf. Nigerian Ass.of Hydrogeologists (NAH), Port Harcourt, $19^{\text {th }}-23^{\text {rd }}$ Nov. 1995 